УДК 342

DOI https://doi.org/10.32849/2663-5313/2020.6.29

Павло Коломійщев,

аспірант кафедри конституиійного права та прав людини

Національної академії внутрішніх справ

\title{
КОНСТИТУЦІЙНА ЗАКОННІСТЬ ЯК МЕТОД ТА МЕТА ЗДІЙСНЕННЯ ДЕРЖАВНОЇ ВЛАДИ
}

Стаття присвячена розкриттю спеиифіки конституиійної законності як методу і мети діяльності органів державної влади. Обгрунтовується, що забезпечення конституиійної законності полягає не лише в ї̈ гарантуванні, а й у всеохоплюючій ï̈ дї̈ та стійкості. Це означає неухильне дотримання конституції: в процесі реалізації безпосередньо норм Конституції; в процесі правотворчої діяльності уповноважених органів державної влади; в процесі правореалізаційної діяльності суб'єктів суспільних відносин.

Конституиія і конституиійна законність є поняттями взаємозалежними. Обгрунтовується, що коли конституційна законність не забезпечена, практична реалізація ї̈ приписів зводиться до того, що конституція існує сама по собі, а суспільне життя - саме по собі. У иьому полягає не сутнісне, а формально-юридичне існування конституиійної законності. Встановлено, що у такому разі конституиійна законність не існує навіть із певними застереженнями. На периий план виходить принцип законності, за яким всі державні органи - від законотвория, законодавия до правозастосувача - відштовхуються суто від букви закону, не враховуючи дух останнього. Прикладом може слугувати дія норм Конституиії СРСР та ї союзних республік із домінуванням принципу сочіалістичної законності. Трансформації конституційного регулювання після незалежності України змінили парадигму конституиійного праворозуміння. В основі перебуває уявлення про те, що конституційне регулювання має забезпечувати звеличення права над державою і державним розсудом. Неможливим є ототожнення права як об'єктивної субстанцї̈ із законом, який може відображати суб'єктивізм волевиявлення державної влади.

Доведено, що конституиійна законність перебуває у тісному зв'язку з демократією. Це випливає із ї̈ прояву як принципу конституиійного ладу. Визнання норм Конституиій у рутинному житті, забезпечення ї̈ верховенства у системі діючого права на всій території України є практичним проявом конституиійної законності.

Ключові слова: принцип законності, конституційна законність, конституційний лад, норми конституції, правотворча діяльність, конституційній контроль, правозастосування.

Постановка проблеми. Суспільні відносини завжди потребують упорядкування, незважаючи на їх розвиток та одночасно постійну мінливість. Таке упорядкування вимагає правомірної поведінки учасників, яке грунтується на праві і законності. Суворе і неухильне дотримання норм права усіма учасниками суспільних відносин у своїй сукупності становить правопорядок, який, як вінець, підсумковий результат дії права, немов би замикає ланцюг головних суспільно-політичних явищ зі сфери правової надбудови (правозаконність - законність - правопорядок) [2, с. 98].

Конституційний порядок виступає ядром правопорядку і є результатом реалізації конституційної законності. У найбільш загальному вигляді йдеться про втілення усіма суб'єктами права приписів Конституції України, здійснення ними дій на її засадах і на їі виконання [4; 8, с. 14-15].

Законність - одне із фундаментальних понять юридичної науки й практики, яке містить формальні вимоги законності (законність заради букви) та змістові (верховенство права, правового закону, дотримання та повага прав і свобод людини, справедливості та розумності правозастосування тощо). Безсумнівно, єдність змістових та формальних вимог - основа для конституційної законності, необхідної для забезпечення свободи та реалізації прав громадян, функціонування громадянського суспільства, реалізації демократії, науково обгрунтованої побудови та раціональної діяльності органів державної влади [15, с. 21].

У свою чергу, поняття конституційної законності є відносно новим у вітчизняній юридичній лексиці. Досить небагато робилося спроб опанувати конституційно-правове та філософсько-правове значення цього феномена. Фрагментарний прояв конституційної законності в механізмі конституційного ладу і правопорядку досліджували С. С. Алексєєв, Н. М. Вітрук, М. М. Вопленко, 
Д. А. Керімов, В. М. Кудрявцев, С. А. Лукашова, Н. М. Малеін, Н. М. Оніщенко, С. В. Полєніна, П. М. Рабінович, М. В. Савчин, О. В. Скрипнюк, Ю. Д. Тихомиров, Ю. В. Ткаченко О. В. Щербанюк та інші.

У межах цієї статті спробуємо заповнити цю наукову прогалину.

Мета статті - розкриття правової природи конституційної законності та їі прояву у динаміці суспільних відносин, зокрема шляхи її забезпечення через практику Конституційного Суду України.

Виклад основного матеріалу. Сучасна Конституція повинна бути продуманою моделлю організації всіх сфер життя суспільства із різним ступенем конкретизації кожної із областей [5, с. 21]. Конституційна законність, підкреслює О. Н. Громова, починається не тоді, коли поновлюються права шляхом ухвалення рішень компетентних органів, а тоді, коли будь-які органи починають свою діяльність із дотримання Конституції та слідування їй [1, с. 212].

Конституційна законність є універсальним правовим принципом конституційного ладу держави, на якому базується організація та діяльність усіх органів державної влади, органів місцевого самоврядування, громадських організацій та окремих громадян. У самому загальному вигляді цей принцип можна сформулювати як загальну вимогу, що відображає потребу (необхідність) правомірної поведінки (діяльності) всіх суб'єктів конституційно-правових відносин. Це означає, що прийняття, реалізація та застосування норм права повинні відбутися тільки на основі Конституції та законів України. Свою конкретизацію принцип конституційної законності віднаходить у його загальнообов'язковості, гарантованості (забезпеченості), єдності та реальності, які чітко проявляються в діяльності органів державної влади [14, с. 878].

Зазначена загальнообов'язковість конституційної законності в широкому розумінні формує методи здійснення цілей і задач державної діяльності (вони ж можуть бути способами і засобами цієї діяльності).

Конституція і конституційна законність $є$ поняттями дійсно взаємозалежними. Конституційна законність, без сумнівів, породжується фактором конституції. Разом із тим сутність конституційної законності становить не тільки (і не стільки) факт існування юридичної конституції. Історичний досвід містить немало прикладів того, що як за наявності конституцій де-юре (які існують) складалися неправові, тоталітарні політичні режими, які затверджували інакший, ніж було передбачено цією ж де-юре конституцією, порядок суспільного життя [9, с. 37]. Ілюстрацією може стати нещодавній досвід України після ухвалення КСУ рішення від 30 вересня 2010 року [13], яким фактично було змінено конституційний лад усупереч Основному Закону України, що призвело до фактичної узурпації влади В. Януковичем.

У цьому контексті нагадаємо, що КСУ у рішенні від 11 липня 1997 року № 3-зп/1997 наголосив, що «Конституція України прийнята Верховною Радою України від імені Українського народу (преамбула Конституції України), який відповідно до статті 5 Конституції України має виключне право визначати і змінювати конституційний лад в Україні. Це право не може бути узурповано державою, іï органами або посадовими особами (там же). Отже, прийняття Конституції України Верховною Радою України було безпосереднім актом реалізації суверенітету народу, який тільки одноразово уповноважив Верховну Раду України на її прийняття (речення друге-четверте абзацу першого пункту 4 мотивувальної частини)» [12].

Отже, коли конституційна законність як сукупність способів і методів здійснення цілей і задач державної діяльності не була забезпечена, практична реалізація ï приписів зводиться до того, що конституція існує сама по собі, а суспільне життя - саме по собі. Такі випадки свідчать про формально-юридичне існування конституційної законності, а не сутнісне. I тоді конституційна законність не існує навіть із певними застереженнями. На перший план виходить принцип законності, за якого всі державні органи від законотворця, законодавця до правозастосувача - відштовхуються суто від букви закону, не враховуючи дух останнього. Прикладом може слугувати дія норм Конституції СРСР та її союзних республік із домінуванням принципу соціалістичної законності.

У радянській юриспруденції ототожнення закону й права було ідеологічною необхідністю, оскільки 3 античних часів вважалося, що справедливість є об'єктивною властивістю права, тому правопорядок, утворений законами, які застосовуються владою, мав визнаватися справедливим. У той період у парадигмі радянського державного управління презюмувалося не тільки позитивістське праворозуміння, але й верховенство держави над правом і відповідного цього права на людиною, її права й свободами [7, с. 74].

Трансформації конституційного регулювання після незалежності України змінили парадигму конституційного праворозуміння. В основі перебуває уявлення про те, що конституційне регулювання має забезпечувати 
звеличення права над державою і державним розсудом. Неможливим є ототожнення права як об'єктивної субстанції із законом, який може відображати суб'єктивізм волевиявлення державної влади [6, с. 2162].

Розглядаючи конституційну законність як метод здійснення цілей і задач державної діяльності, а також певні способи і засоби цієї діяльності, слід зауважити, що законність не залежить від прийняття Конституції. Вона бере свій початок з моменту формування волі державно-утворюючого народу про необхідність організації всього суспільного життя на засадах законів, що виражають його волю та інтереси. Саме для забезпечення реалізації цієї волі необхідна така суспільно-правова категорія, як законність. Конституційна законність, будучи сформована початково у суспільній свідомості, надалі реалізується в Конституції як установчому документі державно-організаційного суспільства і за допомогою інших законів [11, с. 163]. Зазначений підхід, який підтриманий також зарубіжною дослідницею I. А. Яшиною, видається нам максимально прийнятним для українського конституційного регулювання і ролі конституційної законності у цьому. Значення конституційної законності ще до початку розроблення Конституції України (або внесення змін до неї) максимально адекватно відображає її сутність із позиції сучасного розуміння співвідношення конституційної законності і законності взагалі [17, с. 51].

Конституційна законність виступає ядром принципу законності, якщо розглядати останній комплексно, вона є найвищим рівнем прояву у державному і суспільному житті. 3 урахуванням цього, як категорія «окремого порядку», вона володіє усіма властивостями, рисами, які притаманні законності в цілому, і разом із тим різниться набором особливих характеристик, що і дозволяють вважати іï найвищим шаром (пластом) законності [17, с. 51].

Передумовою конституційної законності $€$ наявність конституційного законодавства (тут ідеться про закони, прийняття яких передбачено нормами Конституції, а також інші нормативно-правові акти, зміст яких повинен відповідати Основному Закону). При цьому велике значення має якість законодавчої бази, а саме: відсутність колізійності змісту нормативно-правових актів, однозначність термінології, що вживається, висока якість та одноманітність правозастосовної діяльності. Відсутність тих чи інших законів, прийняття яких передбачено Конституцією України, свідчить про порушення норм Конституції України [10, с. 40]. Це, у свою чергу, характеризує державну владу як таку, що порушує режим конституційної законності.

Основна сфера прояву конституційної законності - практична діяльність суб'єктів права. У сучасному суспільстві вона має реальний характер, а її забезпеченню властива спеціально розроблена державою для цих цілей система соціально-економічних, політичних, ідеологічних та владно-юридичних (правових) гарантій [3]. Особливе значення вони набувають у разі комплексного застосування. Саме у такому разі створюються максимальні можливості для перетворення у життя волі всього українського народу, яка втілена у конституційних нормах $[17$, c. 52$]$.

Конституційна законність як метод і мета діяльності органів державної влади полягає, окрім її гарантування, у всеохоплюючій її дії та стійкості.

Це означає неухильне дотримання конституції: в процесі реалізації безпосередньо норм Конституції; в процесі правотворчої діяльності уповноважених органів державної влади; в процесі правореалізаційної діяльності суб'єктів суспільних відносин.

Н. М. Пархоменко з цього приводу підкреслює, що правотворчий та правореалізаційний процес повинен відбуватися виключно на основі Конституції та законів України. Зокрема, під час правотворчої діяльності, особливо законотворчої, всі стадії правотворчого процесу мають відбуватися відповідно до норм Конституції України та інших відповідних законів. Постійним має бути моніторинг законодавчого масиву з метою своєчасного внесення об'єктивно необхідних змін і доповнень, усунення протиріч та систематизація нормативно-правових актів. Правореалізаційний процес, пише Н. М. Пархоменко, є діяльністю суб'єктів суспільних відносин щодо виконання, використання, дотримання і особливо застосування норм права, також має відбуватися відповідно до норм Конституції та законів України [10, с. 40].

Продовжуючи наведену думку української вченої, від себе додамо, що характер суспільного і державного життя вимагае неухильного дотримання та виконання чинних законодавчих та інших норм, серед яких особливе місце належить вимозі дотримання та виконання саме норм Основного Закону України. Адже саме Конституція України $€$ основним джерелом права і виступає мірилом впровадження законності у життєдіяльність усіх учасників суспільних відносин. Визнання норм Конституції у рутинному

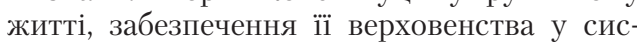
темі діючого права на всій території України 
$€$ практичним проявом конституційної законності.

Крім того, у цьому контексті продовжимо, що конституційна законність як метод і мета діяльності органів державної влади перебуває у тісному зв'язку з демократією, також випливає iз її прояву як принципу конституційного ладу.

Демократія передбачає обов'язок усіх державних органів і гілок влади та їх посадових осіб дотримуватися конституції і діяти сумісно і відповідно до законів. Стійкість демократії визначається не тільки створенням конституції, яка відповідає високим стандартам (зокрема, Конституція України) чи запитам суспільства країни та суспільних класів, націй і народів, груп населення до інститутів конституційного ладу [16, с. 89] У свою чергу, саме демократичний режим, в якому найповніше реалізовані принципи народовладдя, $€$ основою та необхідною умовою встановлення і підтримки істинно конституційної законності - режим поведінки і діяльності владних інститутів, структур, заснованих на правовій Конституції $[16$, c. $89 ; 10$, c. 39$]$.

Отже, конституційна законність гарантується державою, про що свідчить імперативний характер викладення відповідних норм у Конституції України, з одного боку, а з іншого - може бути розглянута як організаційно-правова гарантія забезпечення державного ладу. Гарантованість конституційної законності проявляється у можливост застосування заходів державного примусу до порушників норм Конституції. Відповідальність може наставати як за діяльність, що суперечить нормам Конституції, так і за бездіяльність. Крім того, шляхом визначення у Конституції України повноважень органів державної влади забезпечується їх гарантованість шляхом формалізації та закріплення (узаконення або законність) основних напрямів їхньої діяльності [10, с. 40].

Окремо підкреслимо, що зв'язок конституційної законності і демократії простежується також і в тому, що утвердження конституційної законності можливе виключно демократичними засобами [9, с. 39]. Очевидним є те, що порядок у суспільстві, який не грунтується на законності, може бути досягнутий і без дотримання законності. Встановлюючи і підтримуючи порядок у суспільстві нелегітимними засобами, держава заперечує демократію, нехтує правами і свободами громадян. Із наведенням порядку різко знижується рівень конституційної законності. Нерозривний зв'язок із демократією пов'язує конституційну законність із правами людини, демократичним проявом, гуманістичною скерованістю державної діяльності [9, с. 39].

\section{Висновки}

Коли конституційна законність як сукупність способів і методів здійснення цілей i задач державної діяльності не забезпечена, практична реалізація її приписів зводиться до того, що конституція існує сама по собі, а суспільне життя - саме по собі. Такі випадки свідчать про формально-юридичне існування конституційної законності, а не сутнісне. I тоді конституційна законність не існує навіть із певними застереженнями. На перший план виходить принцип законності, за якого всі державні органи - від законотворця, законодавця до правозастосувача - відштовхуються суто від букви закону, не враховуючи дух останнього. Прикладом може слугувати дія норм Конституції СРСР та її союзних республік із домінуванням принципу соціалістичної законності.

Конституційна законність як метод і мета діяльності органів державної влади полягає, окрім іï гарантування, у всеохоплюючій іï дії та стійкості. А також перебуває у тісному зв’язку з демократією, що випливає з її прояву як принципу конституційного ладу. Це означає неухильне дотримання конституції: в процесі реалізації безпосередньо норм Конституції; в процесі правотворчої діяльності уповноважених органів державної влади; в процесі правореалізаційної діяльності суб'єктів суспільних відносин.

Характер суспільного і державного життя вимагає неухильного дотримання та виконання чинних законодавчих та інших норм, серед яких особливе місце належить вимозі дотримання та виконання саме норм Основного Закону України. Адже саме Конституція України є основним джерелом права і виступає мірилом впровадження законності у життєдіяльність усіх учасників суспільних відносин. Визнання норм Конституції у рутинному житті, забезпечення іï верховенства у системі діючого права на всій території України є практичним проявом конституційної законності.

\section{Список використаних джерел:}

1. Авакьян С.А. Конституция России: природа, эволюция, современность. Москва : Рос. юрид. изд. дом, 1997. 512 с.

2. Алексеев С. С. Государство и право: начальный курс : учебник-конспект. Москва : Юрид. лит., 1993. 192 с.

3. Байтин М. И. Сущность права (современное нормативное правоприменение и грани двух веков). Мосва, 2005. С. 345-360.

4. Басиев М. С. Институт федерального вмешательства как чрезвычайный механизм обеспе- 
чения конституционного порядка на территории федеративного государства: сравнительно-правовой анализ : дисс. ... канд. юрид. наук: 12.00.02. Москва : РУДН, 2007. 213 с.

5. Громова О. Н. Конституционная законность и ее обеспечение в Российской Федерации. Труды Академии управления МВД России. 2011. № 4(20). C. $20-23$.

6. Кокотов А. Н. Право конституции в российском праве. Актуальные проблемы российского права. 2014. № 10 (47). С. 2161-2168.

7. Ливеровский А. А. Рациональная модель конституционного регулирования. Lex Rossica. 2019. № 1(146). С. 70-82.

8. Нарутто С. В. Верховенство Конституции как основа конституционного правопорядка в России. Российское право. 2018. № 3. С. 30-35.

9. Нурадинов Ш. М., Червонюк В. И. Курбанов Б. М. Конституция и конституционная законность. Вестник Московского университета МВД России. 2013. № 6. C. 35-39.

10. Пархоменко H. M. Конституційна законність як мета, вимога та правовий режим: теоретичні аспекти. Альманах права. 2012. Вип. 3. С. 38-41.

11. Раянов Ф.М., Миниахметов Р. Г., Пономарев Д.А. Право и законность в демократическом обществе. Москва: Право и государство, 2004. $200 \mathrm{c}$.

12. Рішення Конституційного Суду України у справі за конституційним поданням Прези- дента України щодо відповідності Конституції України Постанови Верховної Ради України від 1 жовтня 1996 року «Про тлумачення статті 98 Конституції України» (справа щодо конституційності тлумачення Верховною Радою України статті 98 Конституції України) від 11 липня 1997 року № 3-зп/1997. URL: http:// ccu.gov.ua/zagolovok/12-rozdil-i-zagalni-zasadystatti-1-20 (дата звернення: 18.05.2020).

13. Рішення Конституційного Суду України щодо відповідності Конституції України (конституційності) Закону України «Про внесення змін до Конституції України» від 8 грудня 2004 року № 2222-IV (справа про додержання процедури внесення змін до Конституції України) від 30 вересня 2010 року № 20-рп/2010. URL: https:// zakon.rada.gov.ua/laws/show/v020p710-10 (дата звернення: 18.05.2020).

14. Ткаченко Ю. В. Конституційна законність як принцип конституційного ладу. Форум права. 2010. № 4 C. 875-883.

15. Щербанюк О.В. Роль Конституційного Суду України в забезпечення конституційно законності: проблеми та шляхи їі вирішення. Право і суспільство. № 6-2/2014. С. 21-27.

16. Эбзеев Б.С. Правовое государство. Конституционный суд: учебное пособие для вузов. Москва, 1997. 349 с.

17. Яшина И.А. Принцип законности в судебном процессе: конституционная интерпретация : дисс. .. канд. юрид. наук: 12.00.02. Саратов, 2015. 247 с.

Pavlo Kolomiitsev. Constitutional legality as a method and purpose of exercising state power

The article is devoted to revealing the specifics of constitutional legality as a method and purpose of activity of public authorities. It is argued that ensuring constitutional legitimacy lies not only in guaranteeing it, but also in its comprehensive action and sustainability. This means steadfast adherence to the Constitution: in the process of implementing directly the norms of the Constitution; in the process of law-making activities of authorized bodies of state power; in the process of the rightful realization of the subjects of public relations.

Constitution and constitutional legitimacy are interdependent concepts. It is substantiated that when the constitutional legitimacy is not ensured, the practical implementation of its prescriptions is reduced to the fact that the constitution exists on its own and public life itself. This is not the essential but the formal and legal existence of constitutional legitimacy. In this case, it is established that constitutional legitimacy does not even exist with certain reservations. At the forefront is the principle of legality, in which all state bodies from the lawmaker, the legislator to the law enforcer are repelled purely from the letter of the law, without considering the spirit of the latter. An example is the action of the norms of the Constitution of the USSR and its union republics with the dominance of the principle of socialist legitimacy. The transformations of constitutional regulation after Ukraine's independence have changed the paradigm of constitutional law. At the core is the notion that constitutional regulation should ensure the exaltation of the right over the state and state discretion. It is impossible to identify law as an objective substance with a law that may reflect the subjectivity of the will of the state government. It has been proven that constitutional legitimacy is closely linked to democracy. This follows from its manifestation as a principle of constitutional order. Recognizing the norms of the Constitution in routine life, ensuring its supremacy in the system of existing law throughout Ukraine is a practical manifestation of constitutional legitimacy.

Key words: principle of legality, constitutional legality, constitutional order, norms of the constitution, law-making activity, constitutional control, law enforcement. 